\title{
STRUCTURAL MODELLING OF ECONOMIC GROWTH: TECHNOLOGICAL CHANGES
}

Neoclassical and Keynesian theories of economic growth assume the use of CobbDouglas modified functions and other aggregate econometric approaches to growth dynamics modelling. In that case explanations of economic growth are based on the logic of the used mathematical ratios often including the ideas about aggregated values change and factors change a priori. The idea of assessment of factor productivity is the fundamental one among modern theories of economic growth. Nevertheless, structural parameters of economic system, institutions and technological changes are practically not considered within known approaches, though the latter is reflected in the changing parameters of production function. At the same time, on the one hand, the ratio of structural elements determines the future value of the total productivity of the factors and, on the other hand, strongly influences the rate of economic growth and its mode of innovative dynamics. To put structural parameters of economic system into growth models with the possibility of assessment of such modes under conditions of interaction of new and old combinations is an essential step in the development of the theory of economic growth/development. It allows forming stimulation policy of economic growth proceeding from the structural ratios and relations recognized for this economic system. It is most convenient in such models to use logistic functions demonstrating the resource change for old and new combination within the economic system. The result of economy development depends on starting conditions, and on institutional parameters of velocity change of resource borrowing in favour of a new combination and creation of its own resource. Model registration of the resource is carried out through the idea of investments into new and old combinations.

Keywords: economic growth, modelling, structure, technology, new and old combinations

The Institute of Economy of the Russian Academy of Sciences, Doctor of Economic Sciences, Professor, Head of Institutional Analysis of Economic Dynamics Department, e-mail: o_sukharev@list.ru. 


\section{Introduction}

S. Kuznets asserted in 1966: "One can say that since the second half of the XIX century science-based technologies have definitely become the most important source of economic growth in developed countries, power industry, production of combustion engines, production of the electronic equipment, nuclear technologies, biotechnologies being inter alia"'. As we see, the reservation about developed countries is not accidental because four conditions determine economic growth on the basis of technology improvement: initial income per capita, physical capital (and now financial capital, as well), education and health care (human capital) and initial level of the total productivity of the factors. The rate of saving is not a factor of economic growth now as it was earlier, (and it was reflected in the corresponding models). Most likely, it is one of the conditions and it is not always clear how this condition "will work". However, to provide economic growth and to present it in the form of a certain model (it would be desirable to have a simple model), it is necessary to look for the reasons substantiating the change of total productivity of the factors of economic growth, and the forces which define the impact of separate factors.

Taking into consideration that growth depends on the initial state of the enumerated parameters, we have the situation when the next growth stage is defined by all the previous stages, because initial parameters and factors of economic growth are formed here. Technological changes, gathering speed and influence, so that growth rate of income approaches the rate of technological changes, determine modern growth. Technologies can be considered separately, but the rate of such changes is associated with the rate of institutional changes which is though slightly lower, than changes in technologies, but, nevertheless, also approaches the rate of technological changes, strongly defining agents' reactions and technologies development ${ }^{2}$.

One of the elementary decisions on economic growth modeling which is used in a number of Keynesian and neoclassical growth models, beginning from R. Harrod's model to R. Solow and R. Lucas's (the latter use the apparatus of modified production functions only detailing influence of the factors) can be presented as follows ${ }^{3}$. Let it be created product (income) Y1 in a certain point

Kuznets S. (1966): Modern Economic Growth-New Haven, Yale University Press, p.10.

Hence, the theory explaining the origin and development of technologies is necessary. E. Helpman, in particular, also notes absence of such theory: Helpman E. (2012): A Riddle of Economic Growth, Publishing House of E. T. Gajdar Institute, 240 p.

3 Lucas R. (2013): Lectures on Economic Growth, Publishing house of E.T Gaydar Institute, Moscow, 288 p.; Tobin J. (2010): Monetary Policy and Economic Growth, Publishing House "Librocom", Moscow, 272 p.; Harrod R. (2008): Theory of Economic Dynamics, Central Economic-Mathematical Institute of the Russian Academy of Sciences, Moscow, 210 p.; 
of time t1. It is created by the capital available in the country (physical, human and technological) and is defined by investments $\mathrm{I} 1=\mathrm{a} 1 \mathrm{Y} 1(\mathrm{t})$, where a1 norm of investments into GDP. In the next point of time $t 2$ investment will also determine economic growth (as the major component of GDP), but will be carried out due to the norm of investment a2, that is, $\mathrm{I} 2=$ by a2 $\mathrm{Y} 2(\mathrm{t})+\mathrm{H}(\mathrm{t})$, where $\mathrm{H}(\mathrm{t})=\mathrm{h} \mathrm{Y} 1(\mathrm{t})$ is import of the capital presented as a share of the current product (income) of economic system. Then having introduced parameters b1 and b2 - relation of capital to the output in one and the other case, it is possible to get the relationship of development modes of the system, when it switches the strategy from its own development forces to the strategy of use of these own forces plus attraction of the capital from the outside. It is not simply $\mathrm{R}$. Harrod's model, but it's a certain structural modification, though the growth rate is set very much alike as in Harrod's model (where the rate of savings is in numerator). Relation of investments to capital intensity is $\mathrm{dY} 1 / \mathrm{dt}=\mathrm{I} 1 \mathrm{t}) / \mathrm{b} 1$, $\mathrm{dY} 2 / \mathrm{dt}=\mathrm{I} 2(\mathrm{t}) / \mathrm{b} 2^{4}$.

Then, we will create a simple model of economic growth which would consider structural features of economic system development. We will especially pay attention to new combination appearance. This circumstance is an important structural and institutional element of economic changes influencing economic growth.

\section{Statement of Structural Problem of Economic Growth}

Let's present the problem of economic growth in structural substitution ${ }^{5}$. As it has been shown above, the structure influences growth dynamics greatly and creates or limits its possibilities. Such substitution is useful enough in consideration of new products and technologies in comparison with the old

Helpman E. (2012): A Riddle of Economic Growth, Publishing House of E. T. Gajdar Institute, 240 p.; Lucas R. (1981): Studies in Business-Cycle Theory, MIT Press, Cambridge; Lucas R. (1980): "Methods and Problems in Business Cycle Theory", Journal of Money, Credit and Banking, Vol. 12, (no. 4, Part 2: Rational Expectations), 696-715 pp.; Solow R. (1994): "Perspectives of the theory of growth", Journal of Economic Perspectives, Winter, Vol. 8, no. 1, 45-54; Solow, R. M. (2007): "The last 50 years in growth theory and the next 10", Oxford Review of Economic Policy, Vol. 23 (1), 3-14.

4 Harrod R. (2008): Theory of Economic Dynamics, Central Economic-Mathematical Institute of the Russian Academy of Sciences, Moscow, 210 p.; Hansen A.(1964): Business Cycles and National Income, Norton, New York, 784 p.; Harrod R. (1948): Towards a Dynamic Economics. Some Recent Developments of Economic Theory and Their Application to Policy, MacMillan, London, $184 \mathrm{p}$.

5 Sukharev O. S. (2014): Economic Growth, Institutions and Technologies, Finance and Statistics, Moscow, 464 p.; Sukharev O. S. (2012): Evolutionary Economy, Finance and Statistics, Moscow, $800 \mathrm{p}$.

Vol. 13, No 1, 2016: 53-82 
ones. It can also be carried out, having presented the economy consisting of two sectors: manufacturing sector and service sector, industry and agriculture, state and private sectors, backward and advanced regions, either the sectors of economy, or its separate part, for example, industry, and etc. The scheme in the form of dichotomy can always be complicated at the expense of the third, fourth and fifth elements of the structure for consideration. The problem will turn into a numerical mathematical problem. There will be no more elegant correlations, but the decision scheme will essentially give answers to the questions which the researcher is interested in.

Let's suppose that there are "old" development (growth) possibilities in the economy - $\mathrm{x} 1$ (classical factors and product, created by them). New possibilities/products will be designated as $\mathrm{x} 2$. We will consider, that occurrence of new technologies, possibilities and products $\mathrm{x} 2$ is possible for the account of resources borrowing from $\mathrm{xl}$ with some share $\alpha(t)$, changing in time and by means of new possibilities (resources, technologies) measured as shares of $\mathrm{x} 2$ on parametre $\beta(\mathrm{t})$. In other words, $\mathrm{x} 2$ is equal to the resources borrowed for the account of weakening of $\mathrm{x} 1$ plus the created resource. Technology can also be considered as a resource. The general product of such economic system is $\mathrm{y}=\mathrm{x} 1+\mathrm{x} 2$. Then, it is possible to write down ${ }^{6}$ :

$$
\begin{aligned}
& x 2=\alpha x 1+\beta x 2 \\
& y=x 1\left[1+\frac{\alpha}{1-\beta}\right] \\
& k=\frac{x 2}{x 1} \rightarrow \max
\end{aligned}
$$

If the economy has for the object to carry out the development mode with the greatest domination of $\mathrm{x} 2$, that is, new products, technologies, the problem is reduced to the search of maximum according to coefficient $\mathrm{k}(\mathrm{t})$. Three extreme scenarios are possible. Firstly, new possibilities are created exclusively for the account of former combinations, that is, for the account of $x 1$. Then $\beta=0, \alpha=1$. Secondly, combination $\mathrm{x} 2$ arises only for the account of a new resource and will not involve possibility x1. Then $\alpha=0, \beta \rightarrow 1$ (in mathematical sense $\beta \neq 1^{7}$ ), tends to one. Thirdly, the most probable variant when new resource is partially created and is partially borrowed from possibilities of $\mathrm{x} 1$, transforming them for the account of new possibilities ${ }^{8}$. Research of $\mathrm{k}(\mathrm{t})$ on the extremum gives the correlation of the

Sukharev O. S. (2014): Economic Growth, Institutions and Technologies, Finance and Statistics, Moscow, 464 p.

7 Though this case is already a restriction as formally new combination can appear exclusively for the account of new resource without $\mathrm{x} 1$.

8 It is the basic difference in the description of technological development. Many modern economists give it reduced enough, often being guided by J. Schumpeter's principle of 
speed of borrowing and the speed of new resource creation for $\mathrm{x} 2$, depending on the current shares when $\mathrm{k}(\mathrm{t})$ is maximum with restrictions on the derivative sign in the extremum point (maximum t0). The result can be presented in such a way:

$$
\begin{aligned}
& k=\frac{x 2}{x 1}=\frac{\alpha}{1-\beta} \\
& \frac{d k}{d t}=0 \\
& \frac{d k}{d t}>0, t<t 0 \\
& \frac{d k}{d t}<0, t>t 0 \\
& \frac{d \alpha}{d t}=\frac{\alpha}{\beta-1} \frac{d \beta}{d t}
\end{aligned}
$$

At $\mathrm{k}>1$, we have prevalence of $\mathrm{x} 2$ over $\mathrm{x} 1$. That means $\alpha>1 \beta$.

Taking derivative $y(t)$, we will receive the growth rate of the system, consisting of elements $\mathrm{x} 1(\mathrm{t})$ and $\mathrm{x} 2(\mathrm{t})$. Having introduced designation of the velocity of borrowing $\mathrm{V}_{\alpha}=\mathrm{d} \alpha / \mathrm{dt}$ and velocity of appearance of a new resource (possibilities) $\mathrm{V}_{\beta}=\mathrm{d} \beta / \mathrm{dt}$, we will receive the following equation for the growth rate $g_{\mathrm{y}}=\mathrm{dy} / \mathrm{dt}$ :

$$
\begin{aligned}
& g_{y}=(1+k) \frac{d x 1}{d t}+k x 1\left[\frac{1}{\alpha} \frac{d \alpha}{d t}+\frac{1}{1-\beta} \frac{d \beta}{d t}\right] \\
& g_{y}=(1+k) v_{x 1}+k x 1\left(\frac{v_{\alpha}}{\alpha}+\frac{v_{\beta}}{1-\beta}\right) \\
& k=-\frac{v_{\alpha}}{v_{\beta}} n p u \frac{d k}{d t}=0 \\
& g_{y}^{*}=\left[1-\frac{v_{\alpha}}{v_{\beta}}\right] v_{x 1}-\frac{v_{\alpha}}{v_{\beta}} x 1\left[\frac{v_{\alpha}}{\alpha}+\frac{v_{\beta}}{1-\beta}\right] \\
& v_{x 1}=\frac{d x 1}{d t}
\end{aligned}
$$

creative destruction, without its understanding. But technics and technologies develop on "combinatory principle" and structural correlations play a key role (conjugacy, substitution, addition of technologies, properties of adaptation, and etc. play very important role). 
Expression $\mathrm{g}_{\mathrm{y}}{ }^{*}$ is the growth rate of economy in the extremum point $\mathrm{k}(\mathrm{t})$, where $\mathrm{x} 2$ dominates. Using it, it is possible to get conditions under which there is growth/recession of product $\mathrm{g}_{\mathrm{y}}$ in the given economic system and recession in the point, where $\mathrm{x} 2 / \mathrm{x} 1$ is maximal, that is, new combination (product, technology, sector, and etc.) dominates.

The condition of economic growth on $\mathrm{g}_{\mathrm{y}}$ will be:

$$
\begin{aligned}
& v_{x 1}>\frac{k}{1+k} x 1\left(\frac{v_{\beta}}{\beta-1}-\frac{v_{\alpha}}{\alpha}\right) \\
& \text { or } \\
& v_{x 1}>x 1 \gamma(t)\left[\frac{v_{\beta}}{\beta-1}-\frac{v_{\alpha}}{\alpha}\right] \\
& \gamma(t)=\frac{x 2(t)}{y(t)}
\end{aligned}
$$

From expression for $\mathrm{g}_{\mathrm{y}}{ }^{\star}$ - growth rate in the domination point of $\mathrm{x} 2$, when $\mathrm{k}(\mathrm{t})$ reaches maximum, it is possible to write down similarly what should the speed of combination $\mathrm{x} 1$ be for domination of $\mathrm{x} 2$ to be accompanied by decrease $\mathrm{g}_{\mathrm{y}}{ }^{*}<0$ in this point. Growth rate of the living standard within the limits of the model introduced here will be defined with the positive sign by $\mathrm{x} 1$ velocity, speed of structural changes $k(t)$ and growth rate of population which makes inhibitory influence. Let's write down the expression in the following way:

$$
v_{g}=\frac{d g}{d t}=\frac{1+k}{N} \frac{d x 1}{d t}+\frac{x 1}{N} \frac{d k}{d t}-\frac{1+k}{N^{2}} x 1 \frac{d N}{d t}
$$

If we introduce the value of the living standard in the economic system $g=$ $\mathrm{P} / \mathrm{N}$, values of standards for combinations $\mathrm{g} 1=\mathrm{x} 1 / \mathrm{N}, \mathrm{g} 2=\mathrm{x} 2 / \mathrm{N}$ and share $\mathrm{z}=$ $\mathrm{x} 2 / \mathrm{P}$ of new combination in the total created product, it is easy to notice, that $\mathrm{k}$ $(\mathrm{t})=\mathrm{x} 2 / \mathrm{x} 1=\mathrm{z} g \mathrm{~N} /(\mathrm{g} 1 \mathrm{~N})=\mathrm{Z} \mathrm{g} / \mathrm{g} 1$. Then in point $\mathrm{t} 0$ of extremum $\mathrm{k}(\mathrm{t})$, at certain restrictions for $\mathrm{k}(\mathrm{t})$, we will receive:

$$
\frac{1}{g} \frac{d g}{d t}=\frac{1}{g 1} \frac{d g 1}{d t}-\frac{1}{z} \frac{d z}{d t}
$$

Thus, the relative increment of the living standard in the economic system described by the model in the point of the greatest prevalence of new combination over the previous combination $(\mathrm{x} 2 / \mathrm{x} 1)$ is equal to the difference between relative increment of labor productivity in $\mathrm{x} 1$ and relative increment of share $\mathrm{x} 2$ in the total product. 
As we see, the structure and the structural combinations, operating institutions and key growth parameters influence functioning of economic system greatly. Technological structure is the factor of formation of economic structure. To study the growth factors and factors of cumulative productivity separately will be of no use from the point of view of understanding of the mechanism of economic growth of modern economy which develops at high speed. Laws of resources borrowing and conditions of creation (opening) of new resources become the factor of such movement. Thus structure changes cannot be absolutely predicted. In his time the author managed to demonstrate on elementary models, that, for example, various structures can give the same combination of total risk and income.

In the same way, different structures can give identical growth rate, or to become advancing factor on speed relative to other system. In economy situations are possible when income and risk of its receiving increase, synchronously decrease, or income decreases and risk increases, or risk decreases, but income increases. Appearing structures and institutions can be characterized by such correlations that they will predetermine economic dynamics, possibilities of savings use for investments and provision of economic growth. Below there are some diagrams and comments to them (Figures 1-2, 3-4).

In Figures 1-2 development of economic system on iterations is demonstrated. Five iterations are shown, reflecting growth of system's income (economic growth), accompanied by structural changes (Figure 1). It is interesting to note, that maximization model of total revenue is realized, that is, the policy is "reasonable", no damping and social instruments, which would reduce risks of economic growth, are not provided. Therefore the structure becomes simpler. Separate activities which bring no contribution to income gain disappear ( $\mathrm{B}$ and $\mathrm{D})$, and resources are used only for the activities which can increase income as much as possible.

Figure 1. Iterative Change of Economic Structure (First Mode)

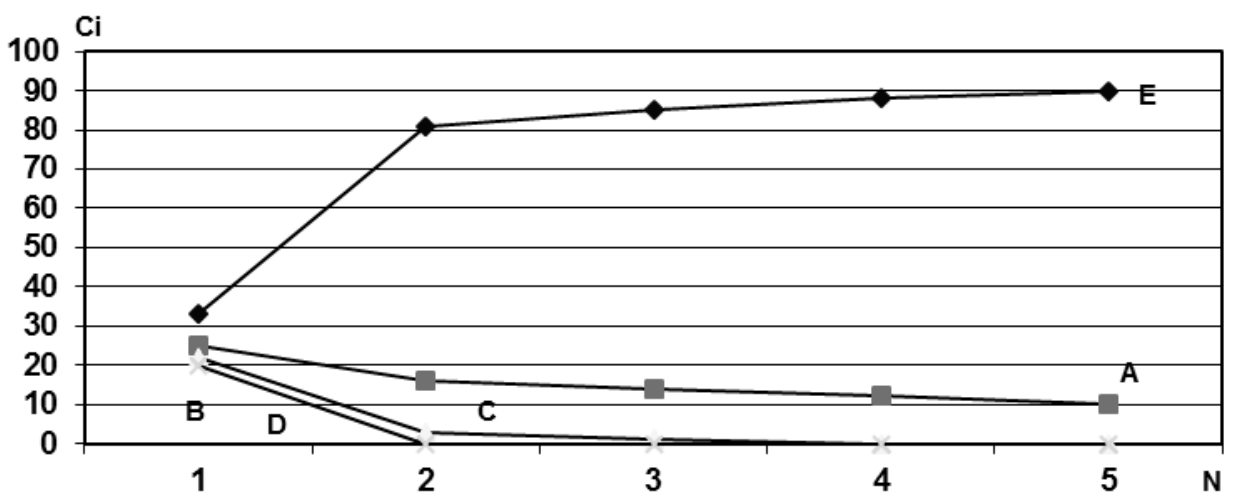


Figure 2 - Iterative Change of Income (First Mode)

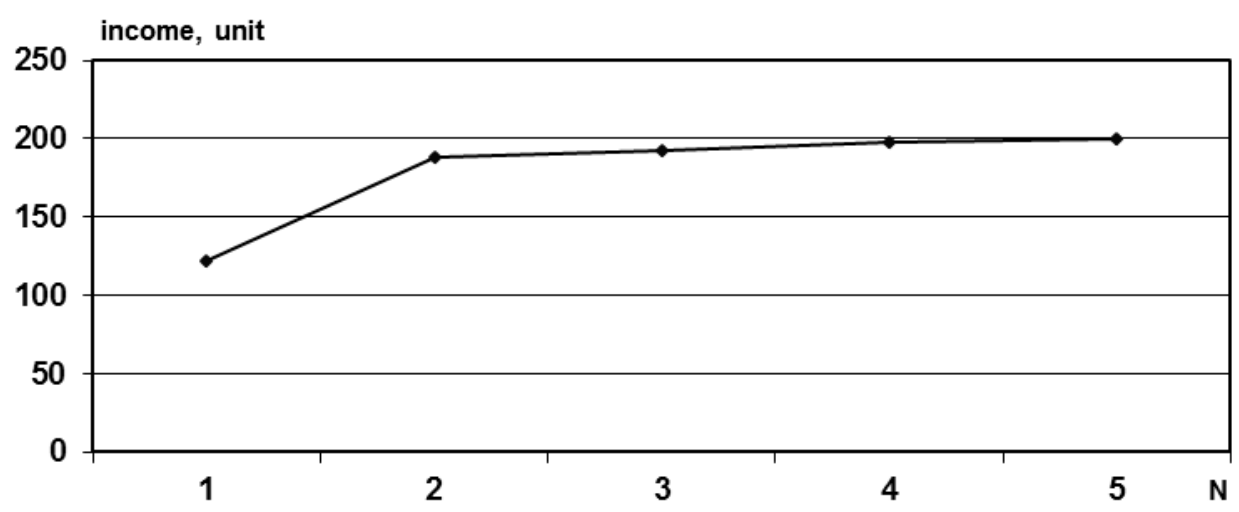

However, on the first iteration economy structure sharply changes. Income also sharply increases (maximum growth on rate and value), at the following stages (iterations) the developed structure is tuning: activities or elements of system $\mathrm{A}$ and $\mathrm{C}$ are reduced, and $\mathrm{C}$ is reduced to zero at the third and fourth iterations and at the fifth iteration there is a structure having two subsystems, $\mathrm{A}$ and E. Income grows slowly enough. Probably, in such economy on the further iterations it will reach a certain maximum, and the economic system will be presented by one element - the kind of activity. If there had been no institutions, structure inertia and state policy, it would have ideally been so. But in practice there are no such results, though separate analogies can be given from this model example. An important conclusion is that at different structures, that is, correlations of the system elements, the system demonstrates different economic growth ${ }^{9}$. The risk of growth in the given example increases. In a qualitative sense its share floats from structure to structure. Risk growth is slowed down in proportion to income, but its share in income approximately remains invariable on last section (iterations 4-5).

The situation, when total revenue of the system and development risk decreases, is reflected in Figures 3-4. It is possible to interpret it as a version of decline in the economy, that is, the tendency opposite to growth, as the total revenue decreases. Income on the first iteration increases, that is, economic growth is observed. Thus the structure changes (two elements are left out of system). Then there is income decrease (recession), and the structure changes essentially: priorities on system elements change. Positions A, E, and D become more priority-driven, than E. Income at 4-5 iterations is stabilized.

Besides if to consider restrictions on the process of iterative development, such result will be especially impressive. 
Figure 3. Iterative Change of Economic Structure (Second Mode)

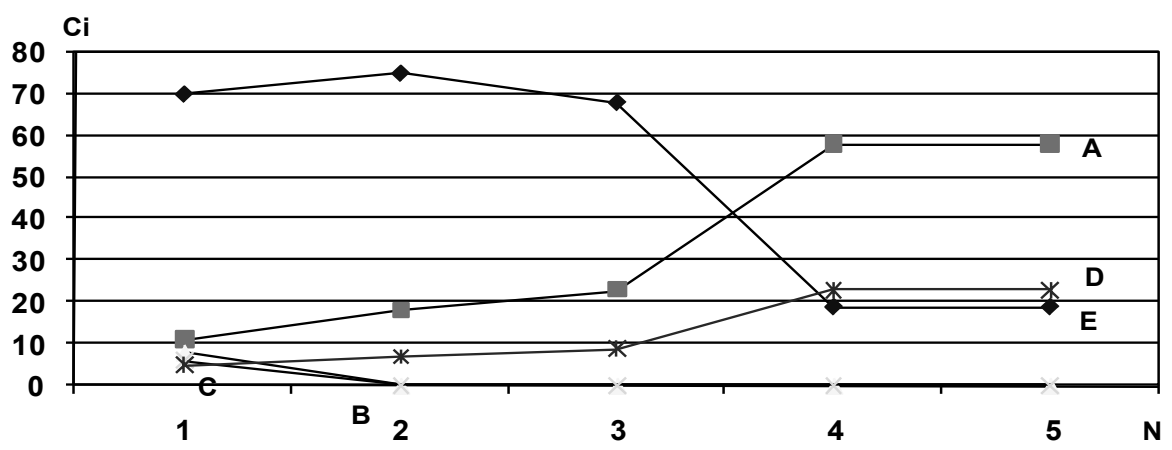

Figure 4. Iterative Change of Income (Second Mode)

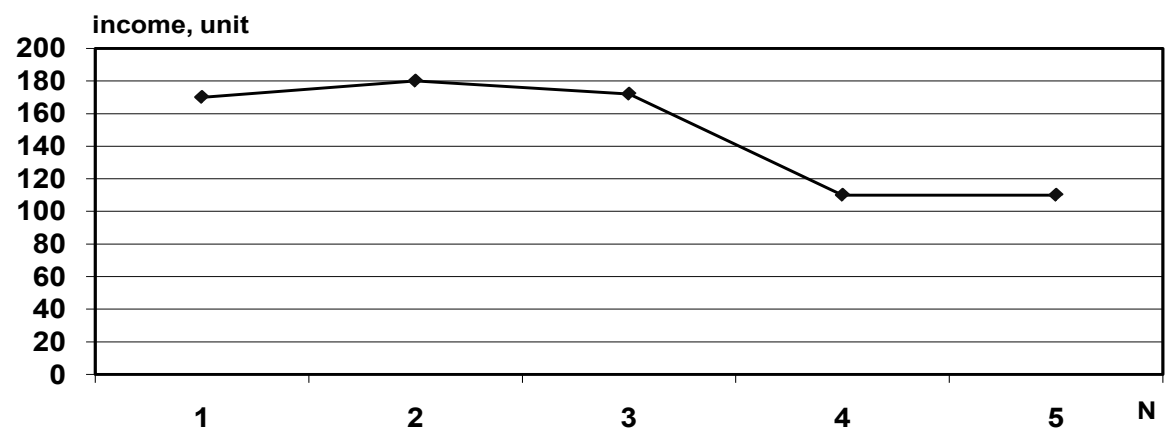

Figure 5:

Economic Structure. Guaranteed Profit and Risk (Expected income R1=160 units is provided by three kinds of activity $\mathrm{A}, \mathrm{D}, \mathrm{E}$. At $\mathrm{R}>\mathrm{R} 1$ and $\mathrm{R} 2=180$ units two more kinds $\mathrm{B}, \mathrm{C}$ are added to these three kinds of activity)

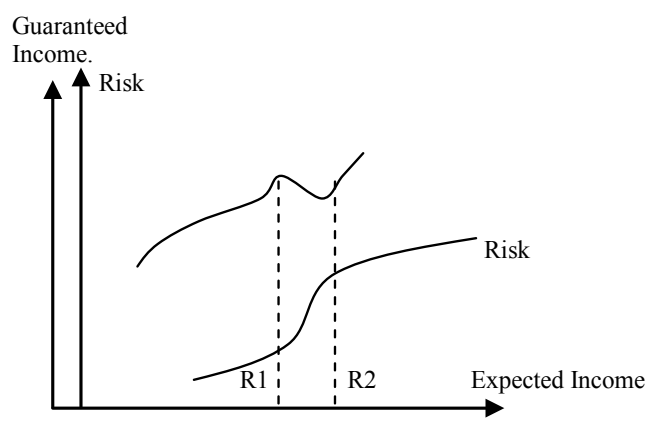


In Figure 5 there is a situation, when the system grows, being guided by certain purposes (expected income), and the risk of economic growth (loss of income) also increases. However, on the section, where it suddenly sharply increases, there is decrease of guaranteed profit of economic system.

Probably, it is connected with the fact, that there are factors of uneven increase of risk that can lower profit. Points R1 and R2 are responsible for conditional 160 and 180 units of expected income. At R $>\mathrm{R} 1$ economy structure becomes more complicated, there appear two more elements, probably, generating uneven change (sharp increase of risk) and the probability of profit decrease. The effect of recession, or short recession appear which is corrected further on by new structure demonstrating greater stability of growth for the account of diversification.

Thereby, it is possible to present the following idea: this growth acquires stability properties for the account of institutions as social dampers of economic growth, and this growth is accompanied by variety and diversification growth of economic and institutional structures. It can regulate deviations and correct short recessions. Economic growth is also possible, when both income and risk increase, but the variety of structure decreases, that is, interfering elements, which do not support economic growth, disappear. This situation can be seen on the given test examples.

As a result there are situations at which income and risk increase with economy growth. But there also can be such modes when income increases and risk is reduced, or risk increases and income is reduced. It is important for institutions not to fix one of such inefficient structures, when the priority of one elements of the system "will overshadow" the development of other important elements for society.

\section{Technological Growth of Economic Systems}

Besides initial knowledge and information, capital assets, the condition of technological growth is, first of all, capital investments, that is, investments into creation of capital welfare, including basic researches ${ }^{10}$. Unevenness of technological growth is not at all connected with certain pauses in innovations which are absent due to the specificity of engineering labor ${ }^{11}$, but with the fact

10 Sukharev O. S. (2014): Economic Growth, Institutions and Technologies, Finance and Statistics, Moscow, 464 p.; Schumpeter J. (1964): Business Cycles: A Theoretical, Historical and Statistical Analysis, McGraw-Hill Book Company Inc., New York and London; Schumpeter J. (1969): The Theory of Economic Development: An Inquiry into Profits, Capital, Credit, Interest and Business Cycle / Trans. by R. Opie, Oxford University Press, New York

11 Between epoch-making innovations on J. Schumpeter [Schumpeter J., 1964, 1969] there is a time interval. They are not constants, their occurrence is discrete, but between 
that the changes velocity is inconstant. It varies with the change of many factors and institutions influencing technological development ${ }^{12}$. Even progress assumes constancy of this velocity according to the logic of things. Trivial models of new technology proceed from comparison of income (profit), which was provided by old technology on some interval, and income, which new technology will provide on the next interval. It would be more correct to compare the income or profit of new technology with the income/profit of old technology if it continued functioning on the following interval of time after introduction of new technology. This "investment" criterion, as it has been already noted, cannot be applied even at the level of a firm, making a choice between old technology and introduction of new technology, as it is insufficient for decision-making and it compares profit of old technology, which have already been received, with possible profit of new technology, which is expected to be received. Probably, the combined decision keeping and increasing efficiency status of old technology and providing the use of new technology will be the most productive. Besides, such contrasting is inappropriate simply because the old technology is not always completely replaced with new technology. It can become more effective and be used together with the development of new technology.

If investments into new technology are carried out, but they do not provide expected efficiency, it is difficult enough to give up this technology quickly on institutional aspects and owing to financial logic and hope, that, all the same, it is necessary to wait for the most effective results. It is a restricted enough representation to believe, as if in the long-term period only basic innovations provide a leap in productivity of economic growth factors, and improving innovations are not capable of it. Such representation is not connected with the essence of engineering processes and technological expansion submitting to cumulative effect, which becomes in itself basic innovations on separate directions of technological development (for the account of new quality of scientific and technical results).

Let's present "investment principle" of technologies change-over, that is, the rule of decision-making at the change of old technology for new one. For

improving and supplementing innovations there are no such intervals. Another matter, that speed of change of improving and supplementing innovations can vary, it is not constant, but it is quite different problem, including institutional organization of the system. Besides, it is probable, that eventually epoch-making innovations will arise less often and actually their influence will be replaced by improving and supplementing innovations increasing like a snowball. This will be a new model of technological and economic growth, though it is also shortsighted to exclude the probability of epochmaking breakthrough.

12 Sukharev O. S. (2012): Evolutionary Economy, Finance and Statistics, Moscow, 800 p.; Sukharev O. S. (2013): Elementary Mathematical Formulation of Crisis and Growth within the Framework of the Cycle Theory, Journal of Economic Theory (Russia), Vol. 1 
this purpose we will designate investments into old and new technologies as $I_{1}$ and $\mathrm{I}_{2}$. All the events occur on time interval $[0, \mathrm{~T}]$. Possible transition/changeover from old technology to new technology occurs at the moment of time t1. In other words, old technology is used during period $[0, \mathrm{t} 1]$ in that case. New technology starts to be used since moment $\mathrm{t} 1$ up to $\mathrm{T}$, that is, period [t1, T]. Then, considering that income of old and new technology and profit are $y_{s}, y_{n}$, $\mathrm{p}_{\mathrm{s}}, \mathrm{p}_{\mathrm{n}}$, accordingly, we will receive ${ }^{13}$ :

$$
\begin{aligned}
& y_{s}=a I_{1}^{\beta} D_{[0, t 1]}(r) \\
& p_{s}=a I_{1}^{\beta} D_{[0, t 1]}(r)-I_{1} \\
& y_{n}=b I_{2}^{\gamma} D_{[t 1, T]}(r) \\
& p_{n}=b I_{2}^{\gamma} D_{[t 1, T]}(r)-I_{2}
\end{aligned}
$$

This recording shows that old technology stopped to bring income/profit at moment $\mathrm{t} 1$. If old technology continues to be used till moment $\mathrm{T}$, discounting changes and the recording also changes:

$$
\begin{aligned}
& y_{s}=a I_{1}^{\beta} D_{[0, T]}(r) \\
& p_{s}=a I_{1}^{\beta} D_{[0, T]}(r)-I_{1}
\end{aligned}
$$

Then for new technology we can write down so:

$$
\begin{aligned}
& y_{n}=b I_{2}^{\gamma} D_{T-t 1}(r) \\
& p_{n}=b I_{2}^{\gamma} D_{T-t 1}(r)-I_{2}
\end{aligned}
$$

It is important to note, that coefficients $\mathrm{a}$ and $\mathrm{b}$ are parameters reflecting technological level, and exponents $\beta, \gamma$ are scale of production which generally cannot coincide for old and new technologies, especially in the long-term period. As is known, the scale of production does not change only on a short interval. Therefore it is possible to consider $\beta=\gamma$ only for rather short interval of time in the formula. Actually, if income is specified as $y=$ an $I^{\beta}$, factor $\beta$

13 In a strict variant it is necessary to consider the different value of money invested now and in a time period $[0, t 1]$, having carried out discounting. But the norm of discount $r(t)$ should also change and depend on $\mathrm{I}_{1}$ and $\mathrm{I}_{2}$, if time period is considerable, so $\mathrm{r}=\mathrm{F}\left(\mathrm{I}_{1}, \mathrm{I}_{2}\right.$, $\mathrm{t})$. Hence, there are no simple and trivial mathematical calculations any more. It is possible to designate discounting procedure in such a way:

$\mathrm{D}(\mathrm{r})=\sum_{\alpha=1}^{t} \frac{1}{(1+r)^{\alpha}}$

Accordingly, $\mathrm{t}$ is for old technology $\mathrm{t} 1$ and for new technology - $\mathrm{T}$. 
means income elasticity on capital I. To claim, that coefficient $a=A L^{1-\beta}$ is also incorrect. Though, aspiration to show the identity of representation of income in the form of Cobb-Douglas production function seems to be natural. The matter is that Cobb-Douglas function at time interval increase should assume the change of substitution coefficients of labour and capital as this correlation changes, it cannot be constant at structural changes of economy and increase of technological level.

The optimum value of investments into old and new technologies can be defined from the condition:

$$
\begin{aligned}
& \frac{d p_{s}}{d I_{1}}=0, \\
& \frac{d p_{n}}{d I_{2}}=0
\end{aligned}
$$

Whence there is the following decision on what investment are necessary for the profit of technology use to be maximum at corresponding restrictions concerning change of profit function ${ }^{14}$ :

$$
\begin{aligned}
& I_{1}=\left[a \beta D_{[0, T]}(r)\right]^{\frac{1}{1-\beta}} \\
& I_{2}=\left[b \gamma D_{[t 1, T]}(r)\right]^{\frac{1}{1-\gamma}}
\end{aligned}
$$

The condition of change of technologies can be written down on the value of the received income, having substituted the value of investments maximizing profit for one and the other technology, and comparing the expected income for the same period of functioning (T-t1). Then we will receive:

$$
\begin{aligned}
& y_{s[T-t 1]} \leq y_{n[T-t 1]} \\
& \frac{a}{b} \leq \frac{I_{2}^{\gamma} D_{[t 1, T]}(r)}{I_{1}^{\beta} D_{[0, T]}(r)} \\
& \frac{a^{\frac{1}{1-\beta}}}{b^{\frac{1}{1-\gamma}}} \leq \frac{\gamma^{\frac{\gamma}{1-\gamma}}\left[D_{T-t 1}\right]^{\frac{1}{1-\gamma}}}{\beta^{\frac{\beta}{1-\beta}}\left[D_{T}\right]^{\frac{1}{1-\beta}}}
\end{aligned}
$$

14 Certain condition on the first derived function or the second derivative should be less than zero. 
If to consider in a very strained case that $\beta=\gamma$, then the criterion will be registered simply enough:

$$
\frac{a}{b} \leq \frac{D_{T-t 1}}{D_{T}}
$$

Thus, change of technologies, that is, preference of new technology before the old one will be defined by the operating time of old technology, the norm of discount and the moment when there appears a new technology. In other words, it strongly depends on percent and does not depend on the scale of production according to old and new technologies. The output factor, or technological level should be $b>$ a $\mathrm{D}_{\mathrm{T}} / \mathrm{D}_{\mathrm{T}-\mathrm{t} 1}$ or be equal to this value for the change-over in favour of new technology to occur. The idea about equality of coefficients of scale cannot be considered correct. In this connection, it is necessary to write down the production function for one and the other technologies separately, not only with its own coefficient of technological level, but also with its own scale coefficient.

The condition written down through the correlation of profit for the time period, when old technology is operating and new technology is appearing, will be:

$$
a I_{1}^{\beta} D_{T-t 1}(r)-I_{1} \leq b I_{2}^{\gamma} D_{T-t 1}(r)-I_{2}
$$

Substituting the optimum quantity of investments for one and the other technologies, it is possible to receive the condition for $\mathrm{a} / \mathrm{b}$ which should be less, than a certain value in the inequality on the right or be equal to it. Having done the necessary calculations, we will get:

$$
\frac{a^{\frac{1}{1-\beta}}}{b^{\frac{1}{1-\gamma}}} \leq \frac{D_{T-t 1}^{\frac{1}{1-\gamma}} \gamma^{\frac{1}{1-\gamma}}\left(\gamma^{\gamma}-1\right)}{\left\{\beta^{\beta} D_{T}^{\beta} D_{T-t 1}-1\right\}\left(\beta D_{T}\right)^{\frac{1}{1-\beta}}}
$$

At $\beta=\gamma$, we have the condition of transition to new technology:

$$
\frac{a}{b} \leq\left[\frac{D_{T-t 1}}{D_{T}}\right]^{\frac{1}{1-\beta}} \frac{\beta^{\beta}-1}{\beta^{\beta} D_{T}^{\beta} D_{T-t 1}-1}
$$

It would be necessary to note, that the complexity of similar conditions sharply increases on a large number of technologies. Even in this case not so "vivid" assumptions are made. They cannot be transferred on a long interval of economic system evolution. It is possible to lower a little the "lifeless" character 
of use of "investment principle" in the choice of technology for the account of structural statement of the problem of technological growth (changes).

Let's show the appearance of new combinations on the elementary example as well, refusing the "investment principle", when new technologies of one class supersede technologies becoming outdated, and there is borrowing of the resource from one possibilities in favor of others. However, "exclusion" does not occur according to "the linear logic", introduced by the principle of "creative destruction", that the new supersedes the old, but for the account of creation of new resource for new combination. It can "root itself" in the economy only this way. Let's introduce $I_{s}=f_{1}\left(r_{s}\right)$ and $I_{n}=f_{2}\left(r_{n}\right)$, resource (investments) into previous and new technologies accordingly and accept, that eventually the use of this resource changes on logistical curve and having accepted that $\alpha$ is a share of resource borrowing from previous technologies in favor of new one and $\mu$ is a share of newly created resource for new combination. All the parameters including $r_{n}$ and $r_{s}$ - profitability parameters of new and previous technologies - are time functions. $D$ is income of the whole system consisting of old and new technologies. Income which is provides by old and new technologies are $D_{s}, D_{n}$ accordingly. Their correlation is $\beta=D_{n}$ / $D_{s}$. There are the following correlations for economic system, taking into consideration that $\alpha=I_{n} / I_{s}, D=D_{s}+D_{n}, \beta=D_{n} / D_{s}, r_{s}=D_{s} / I_{s}, r_{n}=D_{n} / I_{n}$, the resource borrowed by new technology is $\alpha I_{s}$ :

$$
\begin{aligned}
& r_{n}(t)=\frac{D_{n}(t)}{\alpha(t) I_{s}(t)} ; \\
& r_{s}(t)=\frac{D_{s}(t)}{I_{s}(t)} ; \\
& r_{n}(t) \alpha(t)+r_{s}(t)=\frac{D(t)}{I_{s}(t)} ; \\
& \frac{r_{s}(t)}{r_{n}(t)}=\frac{\alpha(t)}{\beta(t)} ; \\
& r_{s}(t)=\frac{D(t)}{I_{s}(t)} \frac{1}{\beta(t)+1} ; \\
& \gamma(t)=\frac{\alpha(t)}{1+\alpha(t)} .
\end{aligned}
$$

If to accept, that the resource is borrowed by new combination, then change of the old system profitability will depend on created income, quantity 
of the resource used by old technologies, share of resource borrowing and its change in time. In time all parametres vary, and appearance of new combination is probable. The problem will be especially complicated, if some combinations appear in the system at once and if the resource is borrowed only partially, and in a less degree, but new combination is created in larger degree. Planning can also set profitability on sectors, or orient on the parameter value $\gamma$ $(t)$. It will also mean, that functionally planning is aimed at projecting, creating new economic structure, operating its change, creating possibilities for new combinations or programming this appearance. Thereby planned values are not macroeconomic parameters of standard number (gross domestic product, inflation or investments), but relative parameters characterizing structural dynamics of economic system. Or the projects on one and the other groups of parameters should be somehow coordinated. It will require creation of models of absolutely different type. Such approach can conditionally be called structural planning, and from the point of view of strategic prospect for the development of economic system it has everlasting value.

The superiority of new combination becomes obvious under condition $r_{n}$ / $r_{s}>1$, that corresponds to condition $D(t) /\left[\alpha(t) r_{s}(t) I_{s}(t)\right]>1 / \gamma(t)$.

Let the necessary resource for the development of new combination be $I_{n}^{p}$. Let us assume that the resource value for new combination is formed at the expense of borrowing of resource $R_{1}$ from previous combination plus newly created resource $R_{2}$. Proceeding from it, $\alpha=R_{1} / I_{s}, \mu=R_{2} / I_{n}$. Then, $I_{n}=\alpha I_{s}+\mu$ $I_{n}$. Whence

$$
I_{n}=\frac{\alpha I_{s}}{1-\mu}, \mu<1 .
$$

Let's consider that $\alpha$ and $\mu$ do not change eventually for simplification (but generally it not so)

$$
\frac{d I_{n}}{d t}=\frac{\alpha}{1-\mu} \frac{d I_{s}}{d t}
$$

If $\mu=1$, the resource for new combination is created in full volume, without borrowing resources from old combinations, $\alpha=0, R_{2}=I_{n}, R_{1}=0$. In this case the resulted expression degenerates, and formation of new combination occurs entirely at the expense of new resource. If $\alpha=1$, the new combination arises exclusively at the expense of the resource of old combinations $R_{1}=I_{s}, R_{2}=0, I_{n}=I_{s}, \mu=0$.

When the resource, which the arising combination has, is less than the resource necessary for its development, technological development is difficult 
and the prospect of new combination has no resource bases. This is described by a following inequality:

$$
\frac{I_{n}^{p}(t)}{I_{s}(t)}>\alpha \frac{1}{1-\mu} \text {. }
$$

Development of new combination has positive prospect, if

$$
\frac{I_{n}^{p}(t)}{I_{s}(t)} \leq \alpha \frac{1}{1-\mu} \text {. }
$$

Considering logistic character of $I_{s}$ and $I_{n}$, change, we will write down

$$
\begin{aligned}
& I_{s}=\frac{a_{s}}{1+b_{s} e^{-t}} ; \\
& I_{n}=\frac{a_{n}}{1+b_{n} e^{-t}} .
\end{aligned}
$$

The equations of logistic growth will be

$$
\begin{aligned}
& \frac{d I_{s}}{d t}=k_{s} I_{s}\left(a_{s}-I_{s}\right) ; \\
& \frac{d I_{n}}{d t}=k_{n} I_{n}\left(a_{n}-I_{n}\right) .
\end{aligned}
$$

Having empirical data on the development of old combinations and applying the least squares method, it is possible to receive coefficients $a_{s}, b_{s}$. Besides, it is possible to estimate parameters $a_{n}, b_{n}$, having data on resource $I_{n}$ for a certain period. Carrying out algebraic manipulations, it is possible to define coefficients $k_{s}, k_{n}$, proceeding from system of equations

$$
\begin{aligned}
& a_{n} k_{n}(1-\mu) I_{s}-k_{n} \alpha I_{s}^{2}=(1-\mu) \frac{d I_{s}}{d t} ; \\
& k_{s} I_{s}\left(a_{s}-I_{s}\right)=\frac{d I_{s}}{d t} .
\end{aligned}
$$

The determinate coefficients depend on parameters $\alpha(t)$ and $\mu(t)$. Having the correlation between needful a resource for new combinations development and assessment of the resource used in old combination and influencing operated parameters $\alpha(t)$ and $\mu(t)$, it is possible to estimate development 
possibility of the structure of new and old combinations within the limits of the economic system and institutional restrictions. Moreover, change of parameters $\alpha(t)$ and $\mu(t)$ will essentially be defined by institutional conditions and possibilities of technologies and the resources they have.

If operated parameters $\alpha(t)$ and $\mu(t)$ vary in time (and in general view it is so), the solution becomes complicated. Then the derivative of the expression

$$
I_{n}=\frac{\alpha I_{s}}{1-\mu}, \mu<1
$$

will give the following equation:

$$
\begin{aligned}
& \frac{d I_{n}}{d t}=\eta(t) \frac{d I_{s}}{d t}+V_{\alpha} I_{s} \chi(t)+V_{\mu} \eta(t) \chi(t) ;(* *) \\
& \eta(t)=\frac{\alpha(t)}{1-\mu(t)} ; \chi(t)=\frac{1}{1-\mu(t)} ; \\
& V_{\alpha}=\frac{d \alpha}{d t} ; V_{\mu}=\frac{d \mu}{d t} .
\end{aligned}
$$

The solution of the equation $\left(^{*}\right)$ in the assumption of invariable velocities of borrowing and creation of new investments (resource) $\alpha$ and $\beta$, for $I_{s}(t)$ in the initial point $\mathrm{I}_{\mathrm{s}}(0)=\mathrm{I}_{0}$ will be the following expression ${ }^{15}$ :

$$
\begin{aligned}
& I_{s}=\frac{1-\mu}{\alpha} \frac{a_{n}}{1+b e^{-a_{n} k_{n} t}} \\
& b=\frac{1-\mu}{\alpha} \frac{a_{n}}{I_{0}}-1 \\
& I_{n}=\frac{a_{n}}{1+b e^{-a_{n} k_{n} t}}
\end{aligned}
$$

For dynamically changeable velocities of new resource creation and borrowing of old resource, it is necessary to have the law of velocity change to solve the equation $\left(^{* *}\right)$. The velocity of new resource creation $d \mu(t) / d t=f\left(V_{2}\right)$ for new combination can be associated with the velocity of resource opening and velocity of borrowing $\mathrm{d} \alpha(\mathrm{t}) / \mathrm{dt}=\mathrm{y}\left(\mathrm{V}_{1}\right)$ can be connected with the speed of resource exhaustion. Then:

\footnotetext{
15 I am grateful I.A.Rudakov, to Doctor of Physics and Mathematics, Professor, for
} consultation on this decision and use of logistic proportions in economic analysis. 


$$
I_{n}=\frac{\int_{t 0}^{T} y\left(V_{1}\right) d t}{1-\int_{t 0}^{T} f\left(V_{2}\right) d t} I_{s}
$$

How new logista corresponding to $I_{n}(t)$ will be situated depends on correlation of $\alpha$ and $\mu$. At $\alpha<1 \mu$ and $\alpha<1, \mu<1$, the development of new combination $I_{n}$ will correspond to the logista which will be lower than $I_{s}$ (first mode). At $\alpha>1 \mu$, on the contrary, new combination will surpass possibilities of $\mathrm{I}_{\mathrm{s}}$ (second mode). This situation is shown in Figure 6.

Figure 6. Development of Old and New Combinations in Economy

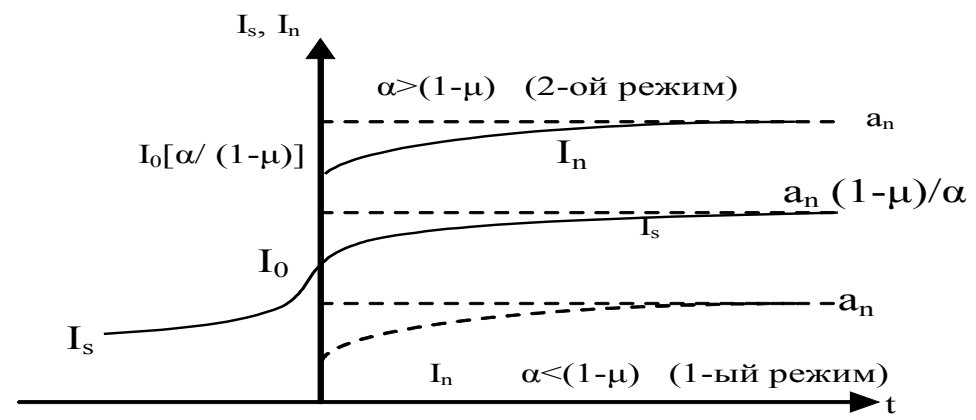

Certainly, resource borrowing can be subordinated to the creation strategy of new technology and new resource. However, this conventional diagram corroborates, the importance of correlation of borrowing velocity and the velocity of new resource creation for system development when these processes are not connected by a certain "internal" law, that is, the velocities do not define each other (in practice there can be a situation when one velocity depends on the other). New combination can exceed possibilities (contribution) of old combination on its share in gross domestic product. However, the development is possible, when there is no such excess and the diagram of new combination is below the diagram of old combination. Another matter if new combination arises, when the old one has already reached a certain development level, say, at $\mathrm{t}>\mathrm{t} 0$. Then it is necessary to get shifted solution, when at $\mathrm{t}=\mathrm{t} 0, \mathrm{I}_{\mathrm{n}}=\mathrm{I}_{1}$, but not at $\mathrm{t}=0, \mathrm{I}_{\mathrm{n}}=\mathrm{I}_{0}$ a $/(1 \mu)$. And $\mathrm{I}_{0}$ is a certain volume of resource of old combination at moment $t=0$. Size $I_{1}$ corresponds to the resource of appearance of new combination $\mathrm{I}_{\mathrm{n}}$, that is, it is 
the resource necessary for new combination to appear at moment t0. This moment can be defined with the formula for new combination $I_{n}$, that is:

$$
\frac{a_{n}}{1+b e^{-a_{n} k_{n} t_{0}}}=I_{1} \text { whence } t_{0}=\frac{\ln \left[\frac{1-\mu}{\alpha} \frac{a_{n}}{I_{0}}-1\right]-\ln \left[\frac{a_{n}}{I_{1}}-1\right]}{a_{n} k_{n}}
$$

Complexity of use of some dependence to describe technological development is that it is difficult to select a curve. Therefore, most likely, there will be no identical curves, for example logistas, for various technologies. To define the moment of new combination appearance with the necessary accuracy is also not obviously possible. As has been shown above, usually available ideas about technological development are reduced to selection of development stages post factum, when technologies are already known and have passed their evolutionary way to some point. In this point the researcher has somehow recognized and classified these technologies, having tied them to the time interval, when these or those of them dominated if to estimate this domination on a certain introduced parameter. Economic growth on the basis of technological development/growth is not necessarily carried out for the account of redistribution of resources of one combinations to others though this process of some resource take away exists.

But the process of new resource creation or opening of resource which makes the basis of the following stage of economic growth [2] is rather important. Thus rate of technological growth on some intervals can be more than the rate of economic growth, as there are braking factors and other subsystems using the laws different from technologies in economic system. The difference in velocities generates the conflict between economy subsystems. There are asynchrony effects in the development, and economic growth becomes unbalanced.

\section{Modes of Competitive Development of Old and New Technological Combinations: Random Example}

Let's consider the situations, when velocity parametres of resources use change differently: monotonously increase and decrease in one or opposite directions. Let's consider, that $I_{n}$ and $I_{s}$ change according to the dependences given below everywhere, and the firm line on the diagrams corresponds to $I_{s}$, a $(t)$, and the dashed line corresponds to $I_{n}, \mu(t)$.

$$
I_{s}=\frac{a}{1+b \cdot e^{-s t}} ; y=\alpha(t) \text { - firm line }
$$




$$
I_{n}=\frac{\alpha(t)}{1-\mu(t)} I_{s} ; y=\mu(t) \text { - dashed line }
$$

The Figures below, they are computer imitations, the diagram on the left is change of $I_{n}$ and $I_{s}$, and on the right - change of $\alpha(t), \mu(t)$. Time in equal intervals is shown on the abscissa axis, parameter $y_{i}$, reflecting the change of specified parametres is on the ordinate axis, and $i$ is an experiment number.

1) $\alpha(t), \mu(t)$ change monotonously: $\alpha(\mathrm{t})$ increases, $\mu(\mathrm{t})$ decreases.

$$
\alpha(t)=0,8+0,1 \operatorname{arctg}(x), \quad \mu(t)=0,3-0,05 \operatorname{arctg}(x)
$$

Figure 7: Growth of Economy Subsystems at Monotonous Velocities Variation, when $\alpha(t)$ Increases and $\mu(t)$ Decreases
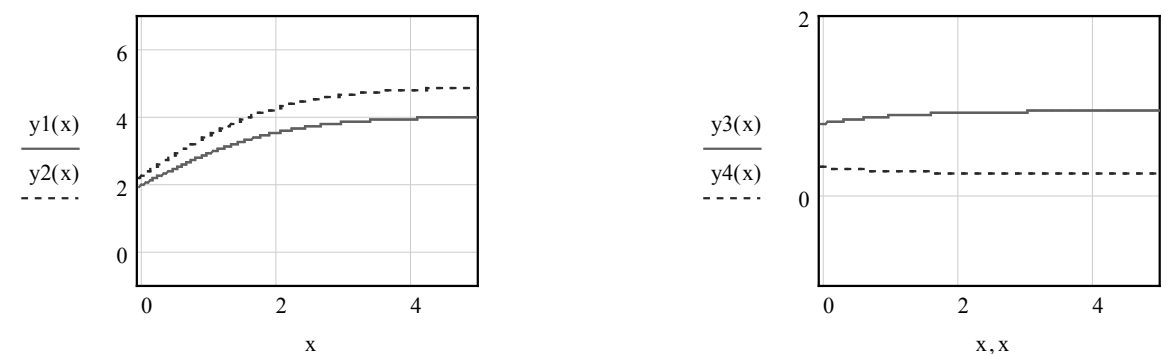

As we see from Figure 7, if velocity $\alpha(t)>\mu(t)$, and the velocity of old resource use increases, and the velocity of new resource decreases a little (monotonous change), "new" combination development steadily dominates over "old" combination (Figure 7, on the left).

Figure 8: Growth of Economy Subsystems (Old and New Combination) at Monotonously Increasing Velocities of Resources Use (Borrowing and Creation)
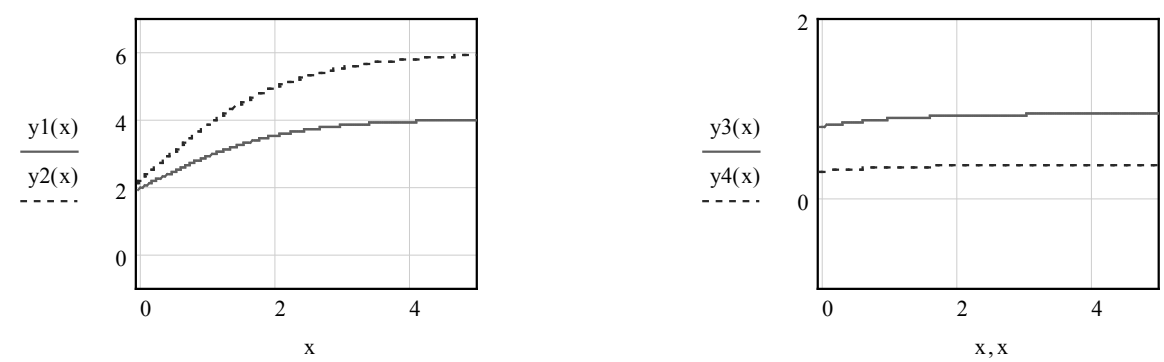
Further on we will consider the situations when both velocities of old and new combinations at first monotonously increase (Figure 8), then monotonously decrease (Figure 9).

Then, we will receive:

2) $\alpha(t)=0,8+0,1 \operatorname{arctg}(x), \quad \mu(t)=0,3+0,05 \operatorname{arctg}(x)$ - increase monotonously

3) $\alpha(t)=0,8-0,1 \operatorname{arctg}(x), \quad \mu(t)=0,3-0,05 \operatorname{arctg}(x)$ - decrease monotonously

Figure 9. Growth of Economy Subsystems (Old and New Combination) at Monotonously Decreasing Velocities of Resources Use (Borrowing and creations)
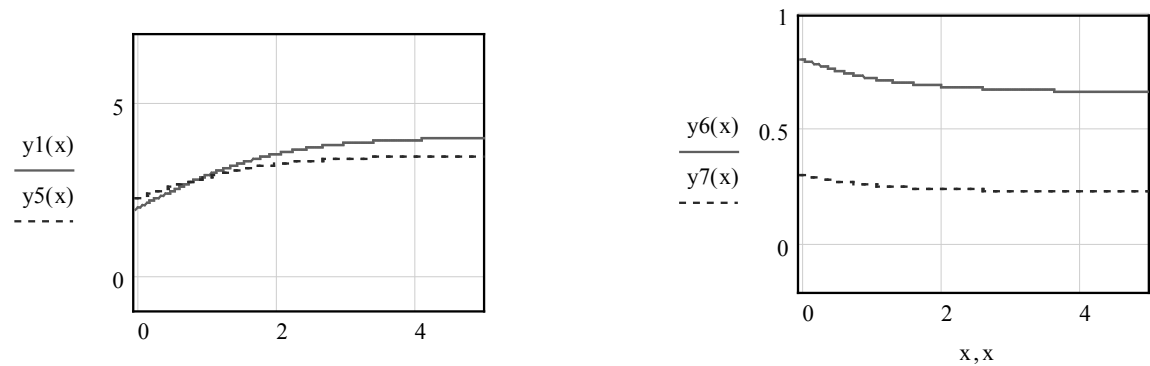

As we see from Figures 8-9, borrowing of resources surpasses resources creation (the firm line in the Figures on the right is above the dashed line). This corresponds to the development mode of the majority of economic systems to a considerable degree.

At monotonous increase of the velocity of resources use by different methods the new combination will grow together with the old combination, however, the lead in the development of new combination from the old one will be essentially above. It can be seen if to compare the diagrams in Figures 8 and 7 on the left, where the line of new combination (dashed line) passes very close to the line of old combination (firm line).

At monotonous decrease of velocities (see Figure 9), the development mode of economic system is such, that at the initial stage "new" combination outstrips the "old" one in development. Its contribution to the system growth is more. Then, however, the old combination dominates over the new one in provision of development (growth) of the system (Figure 9, on the left).

4) $\alpha(t)=0,9-0,1 \operatorname{arctg}(x), \quad \mu(t)=0,3+0,05 \operatorname{arctg}(x)$, that is, $\alpha(\mathrm{t})$ decreases, $\mu(\mathrm{t})$ - increases monotonously (Figure 10). 
Figure 10. Growth of Economy Subsystems (Old and New Combination) at $\alpha(t)$ Decrease and $\mu(t)$ Increase
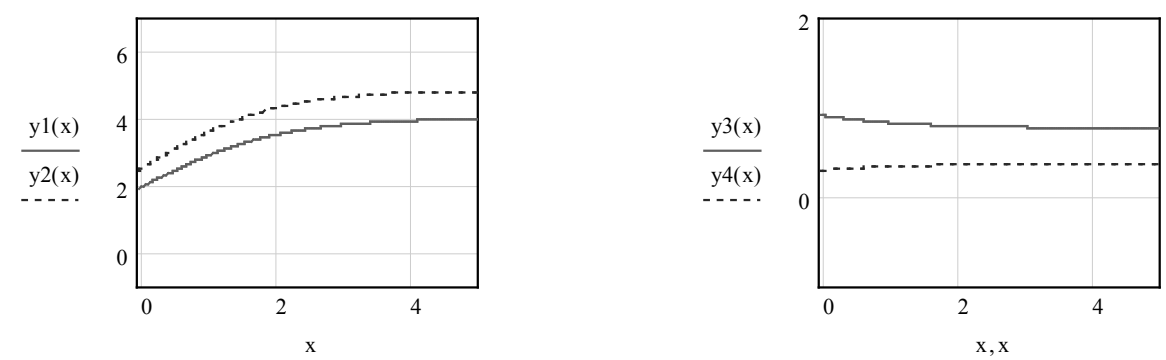

As we see, from Figure 10 (on the left), the "new" combination dominates at such velocities correlation and this type of their change.

Other correlations of changes of the specified velocities of resources change are possible. We will show it below.

5) $\alpha(t)=0,3-0,1 \operatorname{arctg}(x), \quad \mu(t)=0,7+0,05 \operatorname{arctg}(x)-\alpha(t)$ - decreases, $\mu$ $(\mathrm{t})$ - increases. Thereby, as well as in example 4, the speed of old combination decreases, and that of the new one increases. However velocity correlation is different (see Figure 11 on right).

Figure 11 - Growth of Economy Subsystems (Old and New Combinations) At $\alpha(t)$ Decrease and $\mu(t)$ Increase, when $\mu(t)>\alpha(t)$
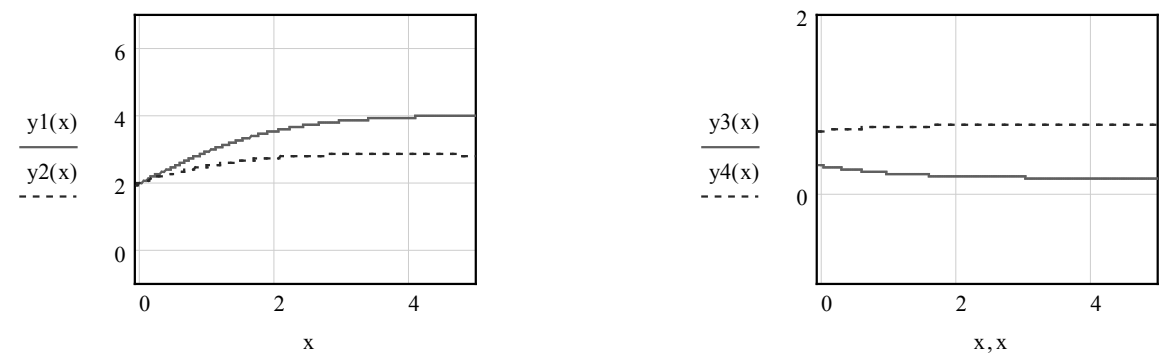

As it is seen in Figure 11 on the right, the velocity is $\mu(t)>a(t)$ on the whole interval of observable change. Then (Figure 11, on the left) the growth of economic system is carried out for the account of growth of both old and new combinations. However, at the initial stage domination of one combination over the other is not obvious. Then, the growth of "new" combination is more modest in comparison with "old" combination.

Now we will consider the situation for the same velocity correlation $\mu(t)>$ $\alpha(t)$, when both speeds monotonously increase and decrease. 
6) $\alpha(t)=0,3+0,1 \operatorname{arctg}(x), \quad \mu(t)=0,7+0,05 \operatorname{arctg}(x)-\alpha(t)$-increases, $\mu$ $(\mathrm{t})$ - increases.

As it is seen from Figure 12 (on the left), the mode is possible when new combination yielding to old combination at the first stage, then starts dominating, bringing the greatest contribution to the development of economic system.

Figure 12 - Growth of Economy Subsystems (Old and New Combinations) at a $(t)$ and $\mu(t)$ Increase, when $\mu(t)>\alpha(t)$
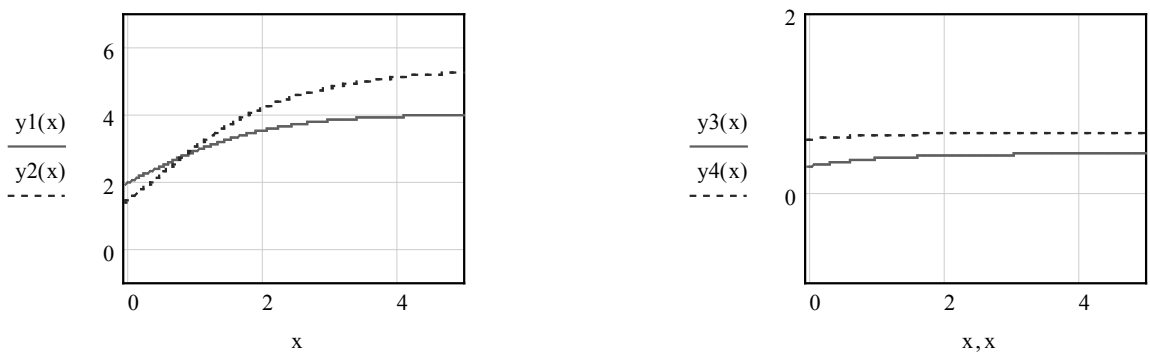

7) $\alpha(t)=0,4-0,1 \operatorname{arctg}(x), \quad \mu(t)=0,7-0,05 \operatorname{arctg}(x)-\alpha(t)$-decreases, $\mu$ (t) - decreases.

When both velocities decrease, and the velocity of "new" combination is higher, than the velocity of "old" combination at the observable interval, the growth of economic system at the first stage is carried out for the account of the appeared new combination, but then the old combination takes over the initiative and has dominating influence on the development of the system (Figure 13 on the left).

Figure 13 - Growth of Economy Subsystems (Old and New Combinations) at a

$(t)$ and $\mu(t)$ Decrease, when $\mu(t)>a(t)$
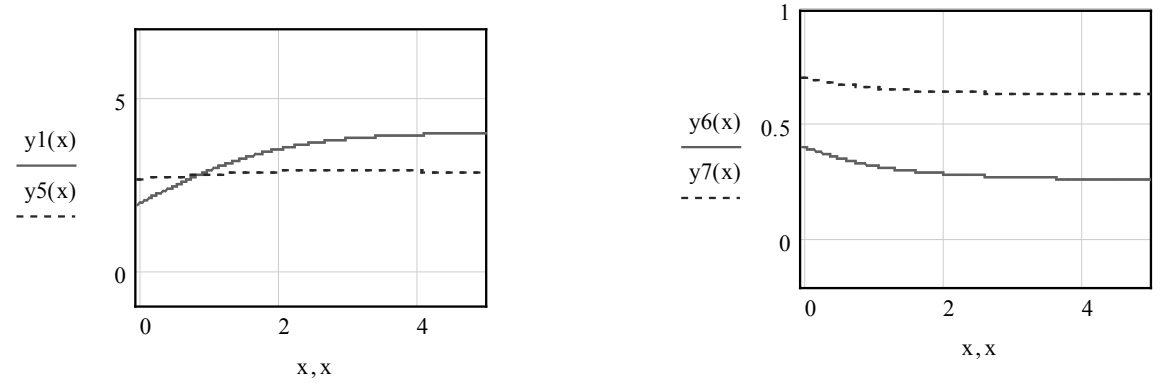
Thus, at velocities increase, if the velocity of new combination is higher, than the velocity of old combination, development occurs for the account of new combination, making the stronger impact. However, at velocities decrease, when the velocity of new combination surpasses the velocity of old combination, the development, on the contrary, is carried out for the account of old combination.

The scenario is possible, when at velocity decrease of old combination and velocity increase of the new one, the development will be observed for the account of new combination (Figure 14, on the left), thus $\mu(\mathrm{t})>a(\mathrm{t})$ it.

8) $\alpha(t)=0,3-0,1 \operatorname{arctg}(x), \quad \mu(t)=0,8+0,05 \operatorname{arctg}(x)$ - $\alpha(\mathrm{t})$-decreases, $\mu$ (t) - increases.

Figure 14 - Growth of Economy Subsystems (Old and New Combinations) at $\alpha(t)$ Decrease and $\mu(t)$ Increase, when $\mu(t)>a(t)$
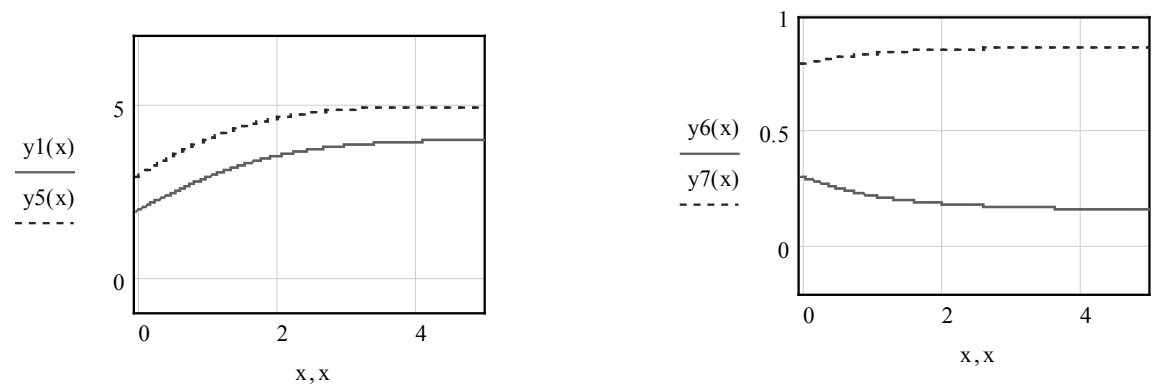

Such effect, when under almost the same conditions the development is quite different in principle, occurs due to strong superiority of the velocity of new combination over the velocity of old combination, that is, $\mu(t)>a(t)$ (Figure 14 on the right)

Thus, there are some development modes (conditions determined by institutions, technologies and operating production factors) at which either the set of old combinations, or the set of new combinations dominates. At the same period of time there is a change of domination mode, when at the initial stage new or old combination dominates, and then, on the contrary, during the greater part of the observation period one of the combinations occupies prevailing position. The grand total is defined by the law of velocities change and their correlation, and by the sign of change - velocity increase $\left(\mathrm{V}{ }_{a}=\mathrm{d}\right.$ $\left.\alpha / d t>0, V_{\mu}=d \mu / d t>0\right)$ or velocity decrease $\left(V_{\alpha}=d \alpha / d t<0, V_{\mu}=d \mu / d t<0\right)$. When $\alpha>\mu$, it means, that the development of economic system occurs for the account of greater resource borrowing from old combination in favor of new one, rather than for the account of opening/creation of new resource, that is a characteristic of parameter - $\mu(\mathrm{t})$. For the specified development mode, 
simultaneous velocities increase leads to sharp domination of new combination. Both combinations grow. At simultaneous velocities decrease new combination at first dominates. Then, for some time past, the initiative passes to old combination. At asynchronous velocities change ( $\alpha$-increases, $\mu$ decreases, or $\alpha$ - decreases, $\mu$ - increases) $I_{n}>I_{s}$, the development occurs for the account of new combination, the appearance of which is provided to a greater degree by the resource borrowing from old combination. However, as it is seen in the Figure, old combination also grows. It is a conclusion of basic value. It confirms the thesis that combinatory character of information and technological development provides the condition according to which old combination is also modified and improved at appearance of new combination, sometimes cardinally ${ }^{16}$.

Thus, it is necessary to say with confidence, that at the given efficiency of this process the mode of resource borrowing will provide new combinations development both for the account of it and old combinations in economy.

If there is a mode, when $\alpha<\mu$, the development should occur for the account of resource opening or new resource creation, but not for the account of resource redistribution, that is, borrowing from old combinations. It is a question of prevalence of one process over the other under condition when both processes are observed.

Then at velocities decrease at first new combination surpasses old combination, but then old combination dominates in development in relation to a new combination, though both of them demonstrate growth. However, at two velocities increase, when the speed of new resource appearance is more than the speed of borrowing, old combination provides superiority $\left(I_{s}>I_{n}\right)$ at the initial stage. Then this situation changes, when new combination $\left(I_{n}>I_{s}\right)$ dominates in development.

At velocities decrease at first new combination surpasses old combination, but then old combination steadily surpasses new combination. Hence, change of old combination (resource borrowing) becomes limiting for the development of new combination. At decrease of borrowing velocity, even under conditions of numerical superiority of the velocity of new resource creation, old combination preserves dominating influence relative to new combination. Only when $\alpha$ and $\mu$ increase, the superiority mode of new combinations over old combination is eventually established at mode $\alpha<\mu$. Only at big gap between $\alpha$ and $\mu$, in favor of $\mu$ when $\alpha<\mu$, superiority of new combination is observed $I_{n}>I_{s}$ within the limits of this development mode (velocities correlation).

16 This circumstance, presence of epy principle of combinatory augmentation, changes the idea of the principle of "creative destruction" in essence. Sukharev, op. cit., 2013 


\section{Conclusions}

The principle of "creative destruction" which introduces linear logics of technological development for the account of primarily borrowing of resources from old to new technologies is not the only one opportunity of explanation the economic development associated with the emergence of new combination (technology). The principle of "combinatory compounding" operates when it is important not only how to borrow resources from the old combination but how it is created, "combined".

The speed of borrowing of resources from the old combination and the speed of new resource creation (emergence) for new combination determine the mode of economic development, competition, different combinations (old and new). Of course, the time and the process of new resource creation will affect the character of the system's economic growth. In the article on the example of using a logistic curve these various modes of development are shown.

When the velocity of borrowing (exhaustion) surpasses the velocity of new resource creation, new combination dominates over old combination as the possibilities of old combination are exhausted, but the prevalence value is different and is defined by increase/decrease of velocities which can asynchronously (one velocity increases and the other decreases), or synchronously (both velocities change in one direction, either increase or decrease) change. However, at decrease of two velocities, the mode when old combination dominates over new combination is possible if the given elements of the economic system grow. The overall result is defined by velocities correlation and the laws of their decrease. Growth of old and new combinations in this case can slightly differ (Figure 9 at the left).

Certainly, the velocities of resources change are strongly determined by operating institutions. Therefore they are original institutional parametres of the economic system. In each economy they also change under individual laws which should be established. At the same time, it is necessary to note, that despite its convention the analysis carried out can be used not only at the level of the real objects using these or those resources and innovations, but also in the sphere of information both general, and relevant, as the effect of old and new combinations is inherent for information (knowledge) as well, old information being also able to be used and borrowed to form new combination. 


\section{Literature}

- Lucas R. (2013): Lectures on Economic Growth, Publishing house of E.T. Gaydar Institute, Moscow, $288 \mathrm{p}$.

- Sukharev O. S. (2014): Economic Growth, Institutions and Technologies, Finance and Statistics, Moscow, $464 \mathrm{p}$.

- Sukharev O. S. (2012): Evolutionary Economy, Finance and Statistics, Moscow, $800 \mathrm{p}$.

- Sukharev O. S. (2013): Elementary Mathematical Formulation of Crisis and Growth within the Framework of the Cycle Theory, Journal of Economic Theory (Russia), Vol. 1

- Tobin J. (2010): Monetary Policy and Economic Growth, Publishing House "Librocom", Moscow, $272 \mathrm{p}$.

- Harrod R. (2008): Theory of Economic Dynamics, Central Economic-Mathematical Institute of the Russian Academy of Sciences, Moscow, $210 \mathrm{p}$.

- Helpman E. (2012): A Riddle of Economic Growth, Publishing House of E. T. Gajdar Institute, 240 p.

- Hansen A.(1964): Business Cycles and National Income, Norton, New York, 784 p.

- Harrod R. (1948): Towards a Dynamic Economics. Some Recent Developments of Economic Theory and Their Application to Policy, MacMillan, London, $184 \mathrm{p}$.

- Hicks J. (1992): “The Mainspring of Economic Growth”, Nobel Lectures, Economics 1969-1980, Editor Assar Lindbeck, World Scientific Publishing Co., Singapore

- Kuznets S. (1966): Modern Economic Growth-New Haven, Yale University Press, $1966 \mathrm{p}$.

- $\quad$ Lucas R. (1981): Studies in Business-Cycle Theory, MIT Press, Cambridge

- Lucas R. (1980): "Methods and Problems in Business Cycle Theory", Journal of Money, Credit and Banking, Vol. 12, (no. 4, Part 2: Rational Expectations), 696$715 \mathrm{pp}$.

- Solow R. (1994): "Perspectives of the theory of growth", Journal of Economic Perspectives, winter, Vol. 8, no. 1, 45-54.

- Solow, R. M. (2007): “The last 50 years in growth theory and the next 10", Oxford Review of Economic Policy, Vol. 23 (1), 3-14

- Schumpeter J. (1964): Business Cycles: A Theoretical, Historical and Statistical Analysis, McGraw-Hill Book Company Inc., New York and London

- Schumpeter J. (1969): The Theory of Economic Development: An Inquiry into Profits, Capital, Credit, Interest and Business Cycle / Trans. by R. Opie, Oxford University Press, New York 


\title{
Profesor Oleg Sukharev
}

Ekonomski institut Ruske akademije nauka, Moskva

\section{STUKTURNO MODELIRANJE PRIVREDNOG RASTA: TEHNOLOŠKE PROMENE}

\begin{abstract}
Sažetak
Neoklasične i kejnsijanske teorije ekonomskog rasta predviđaju korišćenje KobDaglasove (Cobb-Douglas) modifikovane funkcije i druge agregatne ekonometrijske pristupe kojima se pospešuje dinamika modeliranja. U datom slučaju, objašnjenja ekonomskog rasta baziraju se na logici korišćenja matematičkog racia koji često podrazumeva ideje o agregatnoj promeni vrednosti kao i faktore promana a priori. Ideja o proceni faktora produktivnosti je fundamentalna među modernijim teorijama ekonomskog rasta. Pa ipak, strukturalni parametri ekonomskog sistema, institucije i tehnološke promene, praktično, nisu posebno obuhvaćeni već poznatim pristupima, premda se može reći da tehnološke promene utiču na promenljive parametre proizvodne funkcije. $U$ isto vreme, s jedne strane, odnosi strukturalnih elemenata određuju buduću vrednost ukupne produktivnosti faktora, a sa druge strane, snažno utiču na stopu ekonomskog rasta i njenu dinamiku usled primene inovativnih tehnologija. Ugrađivanje strukturalnih parametara ekonomskog sistema u modele rasta sa mogućnošću procene takvih režima pod uslovima interakcije novih i starih kombinacija, predstavlja osnovni iskorak u razvoju teorija ekonomskog rasta/razvoja. Time se, svakako, stimuliše politika ekonomskog rasta koja proističe iz strukturalnih odnosa i odnosa koji su prepoznatljivi u datom ekonomskog sistemu. Ovakvi modeli najčešće koriste logističke funkcije koje ukazuju na promene u korišćenju resursa kako za stare kombinacije tako i za nove unutar ekonomskog sistema. Rezultat razvoja ekonomije zavisi od startnih pozicija, ali i od institucionalnih parametara brzine promena korišćenja tuđih resursa u korist novih kombinacija i stvaranja sopstvenih resursa. Modeliranje resursa je sprovedeno kroz ideju investiranja u nove i stare kombinacije (tehnologije).

Ključne reči: ekonomski rast, modeliranje, struktura, tehnologija, nove i stare kombinacije
\end{abstract}


